Marta Śliwa

Uniwersytet Warmińsko-Mazurski, Olsztyn

e-mail: marta.sliwa@uwm.edu.pl

\title{
Estetyka sztuki pradziejowej. Figuralne przedstawienia kobiece w sztuce epoki kamienia w Europie
}

DOI: http://dx.doi.org/10.12775/RF.2018.014

... A sama sztukę można określić jako rzetelna próbę oddania najwyższej sprawiedliwości widzialnemu światu przez wydobycie na światło dzienne wielorakiej i jedynej prawdy, kryjacej się w każdym jego aspekcie. Jest to próba odnalezienia w jego formach, barwach, świattach $i$ cieniach, w postaci materii $i$ faktach życiowych tego, co podstawowe, trwałe i zasadnicze, ich jedynej oświecajacej i przekonujacej cechy - samej prawdy ich istnienia.

Analiza kultury pradziejowej stanowi dla współczesnego badacza wielkie wyzwanie. Po pierwsze, mamy do czynienia z kulturami, po których pozostały tylko „nieme” artefakty, po wtóre, kultury te posługiwały się zupełnie innym od „naukowego" ${ }^{2}$ opisem świata. H. Gene Blocker w książce The Aesthetics of Primitive Art ${ }^{3}$ stwierdza, że zrozumienie tego, s. $6-7$.

1 J. Conrad, Przedmowa, w: idem „Murzyn z załogi "Narcyza”, Warszawa 1961,

2 C. Lévi-Strauss w Myśli nieoswojonej przyjmuje, że nauka jest sposobem zachowania się Europejczyka, w przeciwieństwie do społeczeństw pierwotnych zdominowanych przez myślenie magiczne. Autor ten jednocześnie nazywa myśl magiczną nauką o konkrecie i twierdzi, że dzięki niej dochowała się do naszych czasów szczątkowa wiedza na temat obserwacji i refleksji. C. Lévi-Strauss, Myśl nieoswojona, PWN, Warszawa 1969.

3 H. Gene Blocker, The Aesthetics of Primitive Art, University Press of America, Lanham, MD 1994. 
jak mógł wyglądać świat „prymitywnego" twórcy zaczyna się właśnie od sztuki, rozumianej tutaj jako punkt początkowy dający możliwość zbliżenia się do, tak nam obcego, widzenia świata.

Analizując dzieła sztuki, opisujemy warstwę formalną, tematyczną czy wreszcie interpretacyjną konkretnych wytworów. Wyróżniamy te poziomy w celu ich poznania, dojścia do prawdy, do ich zrozumienia. Przedmiotem badanym jest konkretne dzieło, jakkolwiek ostatecznym podmiotem badań jest człowiek, ich twórca, jak również ich odbiorca.

Analiza aspektu humanistycznego związanego ze sztuką pradziejową jest szczególnie utrudniona, zważywszy na fakt, że badane dzieła dotyczą społeczności dla nas poznawczo trudno dostępnych, zarówno w wymiarze fizycznym, jak i duchowym. Materiał archeologiczny związany z epoką kamienia jest bardzo obszerny. W paleolicie mamy do czynienia z bogactwem wyobrażeń zwierzęcych, przedstawianych głównie w formie malowideł naskalnych. Wizerunki człowieka stanowią tylko $4 \%$ wszelkich przedstawień ${ }^{4}$ i odnoszą nas do sztuki figuralnej, w zdecydowanej większości przedstawiającej wizerunki kobiece. W neolicie następuje widoczna zmiana tych proporcji na rzecz większej liczby antropomorficznych wyobrażeń. W całej epoce kamienia wśród ludzkich wizerunków przeważają żeńskie przedstawienia. Paleolityczne wyobrażenia ludzkie przedstawiane są w rzeźbie, płaskorzeźbie, grawiurze i w postaci malowideł naskalnych, neolityczne zaś głównie jako przedstawienia figuralne, naczynia antropomorficznych kształtów i z antropomorficznymi zdobieniami, mało jest natomiast przedstawień reliefowych.

W niniejszym artykule zajmiemy się estetyką sztuki pradziejowej na przykładzie paleolitycznych i neolitycznych przedstawień kobiecych w sztuce figuralnej z obszaru Europy.

\section{Charakterystyka kultury archaicznej, kultury typu magicznego}

Człowiek związany z epoką kamienia tworzył specyficzny rodzaj kultury, określany mianem kultury typu magicznego. Ten sposób postrzegania świata charakteryzuje się pewnym synkretyzmem „monodziedzinowości praktyki i kultury" ${ }^{\prime \prime}$, rozumianym jako całościowe ujmowanie rzeczywistości, w której wszystkie zdarzenia są ze sobą ściśle powiązane. Magia zakłada bowiem zasadniczą jedność świata, tego, co się dzieje w człowieku, i tego, co się wydarza poza nim. Rzeczywistość archaiczna

4 Z. Florczak, Sztuka łamie milczenie. Z prahistorii plastyki, Kraków 1974, s. 72.

5 M. Buchowski, W. Burszta, O założeniach interpretacji antropologicznej, Warszawa 1992, s. 19. 
oparta na paradygmacie animistycznym jawi nam się jako spójna i harmonijna.

Martin Heidegger jest twórcą koncepcji, która wydaje się trafnie obrazować ten synkretyczny model kultury. Jest to koncepcja „zamieszkiwania", pokazująca, w jaki sposób ludzie śmiertelni są na ziemi, przy czym oznacza to jednoczesne bycie pod niebem, bycie w obliczu istot boskich i wraz z innymi śmiertelnymi przynależność do wspólnoty ludzi. Mieszkamy w czworokącie złożonym z ziemi, nieba, istot boskich i śmiertelnych, które przenikają się tak, że mówiąc o jednym, jednocześnie myślimy o pozostałych. „Wszystkie cztery [...] mocą jakiejś pierwotnej jedności są jednym" ${ }^{\prime 6}$. Bycie w czworokącie, w jedności, następuje wtedy, gdy śmiertelni ratują ziemię, wyzwalają jej istotę, nie podporządkowując jej sobie ani nią nie władając. Zamieszkując czworokąt, godzą się na niebo, nie ingerując $\mathrm{w}$ jego rytm, "nie robią z nocy dnia, a z dnia nieustającej za czymś pogoni" ${ }^{\prime \prime}$, oczekują nadejścia istot boskich, sami nie czyniąc się bogami, są posłuszni swojej własnej istocie - śmiertelności i umierają „dobrą śmiercią". Pobyt śmiertelnego w czworokącie jest pobytem przy rzeczach, tj. wtedy, gdy rzeczy otoczone są opieką i pozostawione są swojej własnej istocie.

Człowiek związany z kulturą archaiczna, kulturą magiczną, zamieszkiwał. Koncepcja ta stawia w zupełnie innym świetle pradziejowego twórcę, jego sposób postrzegania i sposób myślenia, a nade wszystko jego pełną zależność od natury. Nie chodzi tylko o uzależnienie czysto gospodarcze, gdyż tylko takie w tym przypadku istnieć nie mogło, ale o wpływ owej zależności na mentalność ówczesnych ludzi. Synkretyzm, w jakim uczestniczyli, powodował, że wszelka działalność, praca była postrzegana w pewnych podobnych sobie kategoriach. Wszelkie sfery funkcjonowania: technologiczno-użytkowa, komunikacyjna i światopoglądowa były traktowane jako przejawy jednego działania, przenikały się tak, że umożliwiały traktowanie wszystkich czynności holistycznie ${ }^{8}$.

Człowiek mieszkający w czworokącie nie posługiwał się pojęciem sztuki. W społeczeństwach archaicznych nie istnieje jeszcze sztuka w nowożytnym znaczeniu tego słowa, nie wydziela się w odrębną sferę. Jak

6 M. Heidegger, Budować, mieszkać, myśleć. Eseje wybrane, Warszawa 1977, s. 321.

Ibidem, s. 322.

8 Zob. więcej E. Bugaj, Problemy interpretacji zjawisk sztuki w archeologii w kontekście nieoczywistości sztuki, w: Estetyka w archeologii, Gdańsk 2003, s. 11-20; M. Buchowski, W. Burszta, op. cit., s. 17; E. Kobylińska, Narodziny sztuki jako efekt „odczarowania" świata, „Studia Metodologiczne”, t. 26, 1991, s. 25-45; A. Kuczyńska, Analiza górnopaleolitycznych przedstawień antropomorficznych z obszaru Europy i Syberii w kontekście kultury typu magicznego, "Zeszyty Naukowe Towarzystwa Doktorantów UJ - Nauki Społeczne", t. 1, 2011, nr 2, s. 50-59; A. Kuczyńska-Zonik, Paleolityczna Wenus. Górno paleolityczne przedstawienia antropomorficzne z Europy Środkowo-Wschodniej, Wyd. Uniwersytetu Rzeszowskiego, Rzeszów 2014. 
pisze Ossowski, w społecznościach, „które żyły bujniej, możemy jej szukać we wszystkich dziedzinach życia. Wydaje się więc rzeczą właściwą nie traktować tam sztuki „substancjonalnie” jako pewnej kategorii przedmiotów, lecz raczej „atrybutywnie": stanowi ona wtedy pewien aspekt tamtej kultury, oglądanej przez pryzmat naszego dzisiejszego pojęcia sztuki" ${ }^{\prime}$. Tak pojmowana sztuka i zmiany w niej zachodzące przedstawiają proces rozwoju inteligencji człowieka, jego uzdolnień poznawczych, stanowią klucz do poznania dziejów ${ }^{10}$.

Mając to na uwadze, autorka niniejszej pracy chciałaby porównać antropomorficzne wyobrażenia figuralne w sztuce epoki kamienia i wskazać kierunek, w którym podążał jej twórca.

\section{Współistnienie z naturą i sposoby zdobywania pożywienia a kanon przedstawiania postaci ludzkiej w sztuce epoki kamienia}

Analizując figuralne wyobrażenia postaci ludzkiej z epoki kamienia, można wydzielić dwie, stylistycznie różne, grupy. Pierwsza dotyczyć będzie sztuki paleolitycznej, druga zaś obejmuje neolityczne przedstawienia. Różnica w ujmowaniu postaci wydaje się dość wyraźna.

Zaskakująca jest $\mathrm{w}$ twórczości paleolitycznej różnica $\mathrm{w}$ wyrazie świata zwierzęcego i świata przedstawień ludzkich. Ten pierwszy cechuje niesamowity wręcz perfekcjonizm $\mathrm{w}$ naturalistycznym ujmowaniu zwierząt, pełen zmysłowego, emocjonalnego odczuwania postaci i jej ruchu. W porównaniu z tak „wielką sztuką" antropomorficzne wyobrażenia usuwają się w cień, stanowiąc niewielki procent, zarówno ilościowy, jak i jakościowy, całości zjawiska określanego mianem paleolitycznej sztuki. Wielu badaczy zadaje sobie pytanie, z czego to wynika. Wiemy, że nie ma to związku z nieumiejętnością ówczesnych twórców, którzy nie przyswoili sobie morfologii i nie mogli sobie z nią poradzić. Zatem z czym?

Paleolityczne przedstawienia ludzkie cechuje duży realizm postaci, często z przesadnym zaznaczaniem, szczególnie wśród żeńskich statuetek, piersi i pośladków. Spotyka się też w tej epoce wiele przedstawień stylizowanych, wykazujących pewną tendencję artysty do uproszczenia. Przy czym wydaje się, że w przypadku tych przedstawień stylizacja ta wynika raczej z pewnej nieudolności artysty niż z jego zamierzonego celu. Nieudolność nie ma tu pejoratywnego znaczenia, jest to określenie pozwalające uwidocznić różnicę z twórczością już późniejszą, neolitycz-

9 S. Ossowski, U podstaw estetyki, Warszawa 1958, s. 29.

10 Z. Florczak, op. cit., s. 7. 
na, gdzie stylizacja jest wyraźnie już zamierzona. Stylizacja w całej sztuce paleolitycznej jest sugestywna, ale ani sztuka zdobnicza na przedmiotach, ani malarstwo naskalne nie dopuściły się zdrady w stosunku do obrazu w naturze. Stylizowane, paleolityczne wyobrażenia są grubo ciosane, wyolbrzymione, przenaturalizowane, a z drugiej strony potrafią być już niezwykle geometryczne. Wyjątkowym tego przykładem jest figurka Wenus z Lespuque złożona z kilku piramidalnie ustawionych, rytmicznych półkul stanowiących syntezę ogólnej struktury poszczególnych części ciała, mieszcząca się dokładnie w figurze rombu. Wydaje się, że większość statuetek kobiecych można „wpisać” w tę figurę. Widoczna jest już tutaj potrzeba geometryzacji, mimo że styl paleolityczny jest raczej wiernym oddawaniem i wyraźnym odtwarzaniem postaci, bez narzucania jakiejś interpretacji. Ta potrzeba człowieka wynikała prawdopodobnie z konieczności oznaczenia siebie w nieskończonej rozmaitości natury, jej „wielości rzeczywistości”. Głęboka chęć wprowadzenia jakiegoś ładu w strumieniu wrażeń napływającym ze świata zewnętrznego spowodowała zwrócenie się do najprostszych norm istniejących już w jego świadomości: pewnych powtarzających się sekwencji kresek i linii (pęknięć i rys dostrzeżonych na ścianach skał, korze drzew). Ten porządek wprowadzał nieuniknioną symplifikację, a w dalszym rozwoju i abstrakcję ${ }^{11}$. Występowanie pierwiastka imaginatywnego, jego przewaga w konkretnych wytworach jest świadectwem już abstrakcyjnego widzenia. Wydaje się, że takie widzenie było już obecne w świadomości człowieka paleolitycznego. Najpierw występowało jako rodzaj pewnej notacji, wiele abstrakcyjnych znaków, linii spełniało zapewne funkcję zapisków. Później pojawiło się $\mathrm{w}$ formie ornamentu, a także $\mathrm{w}$ ujęciu już samej postaci. Przykładem abstrakcji w sztuce paleolitycznej, zasługującym na szczególną uwagę, jest przedstawienie postaci kobiecej z Predmosti, wyrażone w bardzo symboliczny sposób, stylem wyprzedzające swą epokę. Odnosi się jednak wrażenie, że są to, w porównaniu $\mathrm{z}$ neolitem, tylko próby. Może są podyktowane wymogami materiału, a może zmianą w sposobie patrzenia na świat, stanowiącą zwiastun nowego kanonu estetycznego. Charakterystyczną cechą dla paleolitu jest również nierówność przedstawień, począwszy od pierwszych stawianych kresek, porównywanych często do rysunków dziecka, po dzieła wyspecjalizowanych w swym fachu artystów. Świadczyć by to mogło po prostu o ewoluowaniu, gdyby nie fakt, że końcowy okres paleolitu łączy się ze stopniowym zanikiem sztuki, która nieprzerwanie trwała od ok. 40 tys. do 10 tys. p.n.e. Mimo tak długiego czasu trwania, tak ogromnego obszaru występowania - od Europy po Syberię, mimo różnych technik i stylów wynikających z siebie w sposób naturalny, może-

11 Ibidem. 
my mówić o jednej, stylistycznie jednorodnej sztuce, w znaczeniu ducha i maniery niezmiennej ${ }^{12}$.

$\mathrm{W}$ neolicie nastąpił przełom $\mathrm{w}$ sposobie ujmowania postaci. Widoczne są zamierzone czynności twórcy w celu ukazania pewnego schematu człowieka. Przedstawienia antropomorficzne pochodzące z terenów Europy Środkowej i Południowo-Wschodniej charakteryzuje duża schematyzacja, będąca poszukiwaniem struktury, zależności pomiędzy proporcjami ciała. Geometryzacja, która występuje w neolicie, pozwala widzieć już w trójwymiarze, poszukiwanie owej zasady ujmowania postaci prowadzi do określenia bryły, w głąb. Postać jest mocno zdefiniowana: wyraźna głowa, często trójkątnych kształtów, tułów, talia, kończyny. Wizerunki kobiece są gibkie, smukłe, kroczące jakby $\mathrm{w}$ tanecznym rytmie, niemal wysportowane ${ }^{13}$. Pojawienie się ornamentu meandrycznego, geometrycznego jest również świadectwem abstrakcyjnego, imaginatywnego widzenia artysty. Pojawiają się one na nowym materiale - ceramice, która staje się ważnym nośnikiem abstrakcyjnych dekoracji, gdzie mocno stylizowane motywy antropomorficzne łączą się często z czysto geometrycznymi. Postacie przedstawiane są en face, a ściany naczyń stanowią naturalne tło całej kompozycji. W kulturach związanych z tym regionem występują też antropomorficzne naczynia świadczące o pewnej syntezie w sposobie postrzegania i ujmowania rzeczywistości. Sztuka związana z kręgiem północnoeuropejskim wykazuje cechy przejściowe pomiędzy tymi okresami. Ujmowanie postaci jest schematyczne, acz jeszcze mało zgeometryzowane. Występowanie ornamentu i niektóre przedstawienia odsyłają do nowego, już zupełnie odmiennego od paleolitycznego kanonu estetycznego. Kanonu, który w dużej mierze posługuje się już abstrakcyjnymi kategoriami. Na jego tworzenie się miały wpływ przede wszystkim zmiany, jakie nastąpiły $\mathrm{w}$ środowisku naturalnym, związane $\mathrm{z}$ odsuwaniem się lodowców, a co za tym idzie zmiany związane z pojawieniem się nowego sposobu penetracji tegoż środowiska.

Człowiek paleolitu był łowcą i poszukiwaczem pożywienia. Zamieszkiwał ziemię, tocząc nieustanną walkę o przetrwanie, pożywienie zdobywał głównie polując na zwierzynę. Żył w „mistycznej symbiozie ze światem zwierzęcym”14, uświadamiając sobie jego „przychylność”. Jest więc rzeczą zrozumiałą tak wielka różnorodność, a w rezultacie perfekcja w odzwierciedlaniu świata, dzięki któremu istniała możliwość przeżycia. Za pomocą sztuki przekazywał to, czym żył, to, co tkwiło w jego umyśle - zwierzę - ‘korzeń życia' epoki paleolitu. Sposób przed-

12 Ibidem, s. 175.

13 H. Wendt, Szukałem Adama, Warszawa 1960, s. 442.

14 M. Eliade, Historia wierzeń i idei religijnych, t. 1, Od epoki kamiennej do misteriów eleuzyńskich, Warszawa 1988, s. 27. 
stawiania był również zgodny z tym, co istniało, był prosty, a w prostocie swej doskonały, pełen realizmu, naturalizmu. Wyobrażenia ludzkie, które w mniejszym stopniu zaprzątnęły umysły społeczeństw paleolitycznych, nie odbiegały od tego kanonu. Stylizacja, jaka się pojawia w tej epoce, „,dopóki trzyma się pewnych granic, jest wynikiem i dowodem spoufalenia się z rzeczywistościa, aktem swobody wobec niej, na który można sobie tylko pozwolić w przypadku wielkiej zażyłości"15. Człowiek paleolitu, żyjąc w wielkiej pokorze wobec natury, dawał temu wyraz w swej twórczości, która była „doskonale dostosowana do szczególnych warunków końca epoki lodowcowej, a pozbawiona tego środowiska, nie potrafiła przeżyć"16.

Zmiany, jakie nastąpiły w końcu epoki lodowcowej, tj. ok. 8 tys. p.n.e. w sposób radykalny przeobraziły krajobraz i klimat. Cofanie się lodowców i ocieplenie klimatu otworzyło nowe możliwości dla rozprzestrzeniania się roślinności i migracji zwierząt. Człowiek musiał przystosować się do nowych warunków, co zapewne nie było prostą sprawa, biorąc pod uwagę chociażby konieczność opuszczenia swych skalnych schronisk $\mathrm{w}$ pogoni za zwierzyną. Zasadnicza jednak zmiana nastąpiła z chwila, kiedy myśliwi powoli przekształcili się w osiadłych hodowców i rolników, porzucając niepewne wyniku łowy na rzecz systematycznie wydającej plony ziemi. Rewolucja neolityczna, o której jest tu mowa, dokonała się stopniowo, wprowadziła uprawę zbóż i oswojenie zwierząt. Nowy styl życia doprowadził do powstania wielu nowych rzemiosł, takich jak garncarstwo, tkactwo, przędzenie, wprowadził podstawowe metody konstrukcji architektonicznej. Odkrycie rolnictwa miało wielkie znaczenie dla rozwoju ludzkiej mentalności. Człowiek zaczął myśleć perspektywicznie. Musiał opracować nowy sposób postrzegania czasu, tak by móc planować prace związane z uprawą ziemi i wykonywać je w ściśle określonej kolejności. Sam fakt uprawy, tworzenia nowego życia i dbałości o nie, zmusił człowieka do bardziej abstrakcyjnego postrzegania rzeczywistości, do myślenia potencjalnego.

Sztuka związana z nową epoką odzwierciedla tę sytuację, urodzajność pola to jest efekt idei, myśli. Oczywiste, że sztuka również w tym kierunku musiała się rozwinąć.

Sztuka neolitu rozwija się $\mathrm{w}$ dwóch kierunkach: jeden polega na dekadencji animalistycznego naturalizmu, drugi zaś na rozwoju sztuki abstrakcyjnej ${ }^{17}$, wyraźne jest przejście od zmysłowo naturalnej sztuki

15 Z. Florczak, op. cit., s. 183.

16 H. W. Janson, Historia sztuki. Od czasów najdawniejszych po dzień dzisiejszy, Warszawa 1993, s. 26.

17 L. R. Nougier, Sztuka pradziejowa, w: Sztuka świata, red. I. Kumińska, Warszawa 1989. 
do połączonego $\mathrm{z}$ naturalizmem abstrakcjonizmu ${ }^{18}$. Artysta nie czerpie już natchnienia ze świata zwierzęcego, lecz poszukuje nowych możliwości wyrazu. Ceramika, staje się jedną z nich, człowiek tworzy, wypala, czaruje i ozdabia motywami, których poszukuje w abstrakcyjnym świecie. W przypadku przedstawień antropomorficznych zmiana nastąpiła w sposobie ujęcia ciała ludzkiego, gdzie wyraźnie widoczna jest tendencja do schematyzowania i poszukiwania pewnych praw, a często do nadawania innych "wymiarów” przedstawianym postaciom. Przyjmując założenia francuskiego strukturalizmu mówiące o niezmiennych, nieuwarunkowanych kulturowo systemach myślenia, o pewnej apriorycznej nieuświadamianej działalności umysłu, nakładającej formy na pewną treść, gdzie „formy te są zasadniczo tożsame dla wszystkich umysłów: starożytnych i nowożytnych, pierwotnych i cywilizowanych"19, możemy pokusić się o stwierdzenie, że widoczna w sztuce tego okresu „maniera” stanowi świadectwo rozwoju umysłowości pierwotnej, stawiającej pierwsze kroki w budowaniu siatki pojęć i kategorii, charakterystycznych dla współczesnego człowieka.

Rozpatrując całokształt sztuki pradziejowej, można stwierdzić, że jest to sztuka wyrażająca proste doświadczenie świata. Sztuka, w której równocześnie występują pierwiastki: abstrakcyjny i naturalistyczny, emocjonalny i intelektualny. Udział uczucia, emocji jest niewątpliwy, w sztuce pierwotnej wyraża się bowiem reakcja świadomości na zewnętrzny świat. Intelektualizm objawia się wtedy, gdy w świadomości odbiorcy, następuje przekształcenie obrazu zmysłowego i odczytanie symbolu dzieła artystycznego. Abstrakcja i naturalizm stanowią dwie przeciwstawne postaci zmysłowego postrzegania świata, poza które sztuka już wyjść nie może. Według J. Gralewskiego występują one w sztuce pierwotnej, w pełnej równowadze, tak, że dzieło znajduje się w centralnym miejscu na osi: naturalizm - abstrakcjonizm ${ }^{20}$. Dzieła sztuki epoki kamienia poruszają się po tej osi, a to, w którym kierunku podąża, jest uzależnione od sposobu doświadczania świata, od stosunku, jaki człowiek miał do natury.

\section{Interpretacje dotyczące przedstawień antropomorficznych w sztuce figuralnej}

Oddzielnym zagadnieniem z perspektywy analizy dzieła sztuki jest próba jego interpretacji. Jak już wspomniano, wyodrębnianie płaszczy-

18 J. Gralewski, Sztuka prymitywna i jej pozycja w rozwoju sztuki, „Przegląd Filozoficzny" 1949, s. 174-203.

19 C. Lévi-Strauss, Antropologia strukturalna, Warszawa 1970, s. 77.

20 J. Gralewski, op. cit. 
zny interpretacyjnej odnoszącej się do dzieł kultury typu magicznego jest zabiegiem czysto intelektualnym, paradygmat animistyczny opisujący ten system nakłada bowiem na badacza konieczność wielopłaszczyznowego syntezowania, które może pozwolić zbliżyć się nam do pradziejowego sposobu postrzegania świata ${ }^{21}$.

Kwestie związane z zagadnieniem interpretacji sztuki pradziejowej nastręczają wiele trudności. Główną tego przyczyną jest fakt, że mamy do czynienia tylko z niemymi artefaktami. Wszelkie koncepcje proponowane przez badaczy w dużej mierze opierają się na analogiach ze współcześnie żyjącymi społecznościami, których sposób życia i gospodarka może być porównywana do paleolitycznych zbieraczo-łowców (np. australijscy Aborygeni, afrykańscy Buszmeni, ludy Ameryki Północnej), czy do ludów wczesnorolniczych. W historii badań nad sztuką pradziejową znajdujemy wiele interpretacji dotyczących głównie antropomorficznych przedstawień figuralnych sztuki paleolitu. Neolityczne przedstawienia kobiece nie są tak „kontrowersyjne” w interpretacji. Przy czym nie należy zapominać o konieczności wielopłaszczyznowego odczytywania poszczególnych zabytków. Zapewne były one nośnikami informacji o technice produkcji i wytwarzaniu, odgrywały rolę w komunikacji i świadomości grupowej - integrowały grupy poprzez przypisanie im określonych, funkcjonujących w grupie społecznej znaczeń, stanowiły także element wiedzy o świecie ${ }^{22}$.

Przedstawienia kobiece dostarczały najwięcej takich możliwości, a konsekwencją tego była wielość interpretacji, czego przykładem są następujące, wybrane, koncepcje:

- Wyobrażenia żeńskie są wizerunkami ówczesnych kobiet, odzwierciedlają rzeczywistość. Koncepcja ta była szczególnie modna w początkach badań nad sztuka, lansował ją między innymi Édouard Piett. Steatopygia, której występowanie stwierdzono u buszmeńskich kobiet, zdawała się świadczyć na jej korzyść, jednak przeprowadzone przez naukowców badania wykazały, że paleolityczne kobiety steatopygii nie posiadały ${ }^{23}$. Koncepcja wyjaśniająca antropomorficzne wizerunki jako przedstawiające rzeczywiste obrazy ludzkie wydaje się, w świecie magii, dość niebezpieczna. Portretowana osoba może być poddawana magicznym zabiegom, często niekorzystnym, podobnie jak w przypadku przedstawiania zwierząt w magii łowieckiej. Poświadczony jest przypadek zniekształconej główki pochodzącej z Dolní Vĕstonic, która prawdo-

21 M. Śliwa, Perspektywa wielokulturowości w estetyce, w: Granice dyscyplinarne w humanistyce, red. J. Kowalewski, W. Piasek, M. Śliwa, Olsztyn 2006, s. 203-211.

22 A. Kuczyńska, op. cit., s. 56.

${ }_{23}$ Z. A. Abramowa, Изображения человека в палеолитическом искустве Евразии, Moskwa - Leningrad 1966. 
podobnie stanowiła realistyczny portret jakiejś „naznaczonej”, wyższej rangą kobiety. W niewielkiej odległości odkryto bowiem grób kobiecy ze zniekształconymi kośćmi twarzy odpowiadającymi zniekształceniom na rzeźbionej główce, a w pobliskiej siedzibie znaleziono drugie podobnie zniekształcone przedstawienie. Łączone jest ono również $\mathrm{z}$ odkrytym grobem kobiety ułożonej na prawym boku, z nogami mocno podkurczonymi, prawdopodobnie związanymi. Lewa strona jej czaszki była mocno zdeformowana wskutek zmian patologicznych. Pochówek ten interpretowany jest jako grób szamanki ${ }^{24}$.

- Paleolityczne przedstawienia kobiece wyrażają estetyczny ideał kobiecości. Grube jest piękne - jest to hasło, które obecne było i czasem jeszcze jest u niektórych ludów m.in. z obszaru Afryki. Kobieta tłusta jest równoważna kobiecie, która nie musi pracować, oznacza dobrobyt, siłę, zaradność. Znane są w niektórych społecznościach praktyki mające na celu sztuczne tuczenie młodych dziewcząt przed zamążpójściem ${ }^{25}$.

Należy w tym miejscu zaznaczyć, że ryzykowne jest twierdzenie o istnieniu jakichkolwiek ideałów w świadomości człowieka związanego z kulturą magiczną, synkretyczny sposób pojmowania świata wykluczał bowiem podział na świat postrzegany zmysłami i świat idei, świat postrzegany umysłem. To rozróżnienie nastąpiło znacznie później i wiąże się z filozofią Platona. W trakcie przywoływania w tym miejscu różnych koncepcji będzie jednak zachowana terminologia stosowana w literaturze.

- Paleolityczne przedstawienia kobiece są erotycznym ideałem kobiety. Ten pogląd głosił Hermann Klaatsch, twierdząc, że uroda kobieca jest wynikiem „długotrwałego procesu doboru, które pod wpływem różnorodnych ras i ludów dokonywał się w łonie ludzkich społeczeństw, doprowadzając do wykwitu różnych typów piękności. Ten proces doboru rozpoczął się u praludzi w chwili, gdy upodobania mężczyzny poczęły zwracać się ku kobietom, których budowa fizyczna obiecała liczne potomstwo" ${ }^{26}$. Twierdził, że wskutek częstego spożywania mięsa znacznie zwiększył się popęd płciowy paleolitycznych myśliwych, a statuetki miały stanowić ideały seksualne ${ }^{27}$.

24 R. Drössler, Wenus epoki lodowcowej, Warszawa 1983, s. 106.

25 R. Meringer, Einigeprimäre Gefühle des Menschen, ihrmimischer und sprachlicherAusdruck, „Wörter und Sachen“ 5/1913, s. 129-171.

26 H. Wendt, op. cit.

27 R. Drössler, op. cit. 
- Żeńskie przedstawienia odnoszą się do kultu żeńskich przodków rodowych, są wizerunkami pramatki ${ }^{28}$. W odniesieniu do paleolitu jest to hipoteza mało prawdopodobna ze względu na częste przywoływanie totemizmu jako pewnego rodzaju pierwotnych wierzeń charakterystycznych dla tej epoki. Koncepcja ta jest prawdopodobna przy założeniu, że statuetki kobiece powstawały w warunkach tworzenia się nowej, już matriarchalnej kultury, która w zasadzie przynależna jest już kulturom wybitnie agrarnym, neolitycznym.

- Kobiece przedstawienia stanowią żeńską personifikację ognia. Świadczy o tym fakt znajdowania większości figurek w pobliżu ognisk. Tokariew, który wysnuwa tę hipotezę, przywołuje na poparcie swych słów przykłady kultu ogniska domowego u macierzysto-rodowych ludów Syberii, np. u Ewenków czczony jest święty ogień - czumu - personifikowany przez żeńską postać bóstwa - eneke ${ }^{29}$.

- Kobiece przedstawienia paleolityczne stanowiły istotę macierzyństwa, uosabiały ideał płodności. Za tą koncepcją przemawia fakt, że większość antropomorficznych wizerunków dotyczy kobiet. $\mathrm{Na}$ wszystkich statuetkach i rytach zaznaczone są organy związane z płodnościa, przy czym ich przesadne kształty, brak rysów twarzy, ogólna ociężałość świadczą bardziej o sylwetce zniekształconej macierzyństwem niż np. o ideale piękności ${ }^{30}$.

- Jedną z najbardziej powszechnych współcześnie hipotez przedstawia LeRoy McDermott. Figurki żeńskie są nośnikiem informacji o kobiecej higienie. Artysta, czy raczej artystki, próbowały odtworzyć swoje ciało, jakby patrząc z góry. Stąd wyolbrzymienie, wyeksponowanie niektórych kobiecych cech (piersi, bioder, brzucha, pośladków) na figurkach jest efektem perspektywy twórcy ${ }^{31}$.

W przypadku interpretacji figuralnych przedstawień kobiecych z okresu neolitu badacze są dość zgodni. Neolityczne przedstawienia kobiece wiązały się z kultem Wielkiej Matki (Magna Mater), uosabiały wszelkie jej aspekty, łącząc w sobie idee pramatki plemienia i matki-ziemi. Wiązało się to $\mathrm{z}$ rolniczym charakterem plemion neolitycznych. W neolicie nastąpiła bowiem pewnego rodzaju "mistyczna solidarność człowieka i roślin" ${ }^{32}$, która w rezultacie spowodowała, że kobieta, czyli

28 S. A. Tokariew, Pierwotne formy religii i ich rozwój, Warszawa 1969.

29 Ibidem.

30 L. R. Nougier, op. cit.; H. Wendt, op. cit., s. 417.

31 L. McDermott, Self - representation in upper paleolithic female figurines, "Current Anthropology" 1996, vol. 37, s. 248; C. N. McCoid, L. McDermott, Toward Decolonizing Gender: Female Vision in the Upper Paleolithic, "American Anthropologist, New Series" 1996, vol. 98, no. 2, s. 319-326. Zob. A. Kuczyńska, op. cit., s. 55-56.

32 M. Eliade, op. cit., s. 29. 
ta która jest płodna, i ta która o płodność ową dba, zaczęła odgrywać decydującą rolę w życiu społeczności. Płodność ziemi utożsamiano z płodnością kobiet, posiadły bowiem tę samą tajemnicę - moc dawania życia. Eduard Pechuël-Löschetak opisuje stosunek wczesnorolnego plemienia Bafioti z Afryki Zachodniej do Matki Ziemi: „W ziemi i z ziemi działa coś co wszystko przenika, jednoczy, przeszłe i przyszłe. W ziemi spoczywają umarli i oni żyjący pójdą kiedyś do ziemi. Z ziemi wyrastają powierzone jej ziarna, odradzają się same z siebie, zapewniają one byt rolnika, z niej wyrastają owoce leśne, trawy i zioła, którymi zaspokajają swój głód. Wszystko co żyje z ziemi czerpie siłę"33. Indianie Ameryki Północnej nazywają ziemię „leżącą kobietą", której piersi to pagórki, kości to skały, oczyma jej są jeziora, rzeki to jej żyły, włosy to roślinność. Z jej ciała wychodzi rodzaj ludzki. Upersonifikowanie ziemi niesie za sobą uświęcenie kobiety, czego wyrazem wydaje się sztuka neolitu, w której większość przedstawień stanowią kobiece wizerunki odzwierciedlające Magna Mater - boginię płodności, miłości, matkę, boginię życia i śmierci.

Należałoby jeszcze nadmienić, że męskie przedstawienia występują $\mathrm{w}$ bardzo małym procencie i $\mathrm{w}$ zasadzie nie stanowią problemu interpretacyjnego. W przypadku sztuki paleolitycznej wiąże się je z magią łowiecka, tym bardziej, że w większości występują wraz z przedstawieniami zwierzęcymi. Występują jako czynnik działający na płodność świata zwierzęcego bądź jako czynnik unicestwiający zwierzynę ${ }^{34}$. Neolityczne przedstawienia męskie interpretowane są jako idole domowe i jako przedstawienia szamańskie dotyczące terenu Europy Północno-Wschodniej związanego z występowaniem neolitycznych społeczności zbieracko-łowieckich. Typowy obraz szamana: figurka bez rąk, z krótkimi nogami, często ze zwierzęcymi kopytami, i rogatą maską na głowie jest obecna $\mathrm{w}$ niektórych przedstawieniach $\mathrm{z}$ tego teren $\mathrm{u}^{35}$. $\mathrm{Z}$ regionu Cisy znane są pierwsze męskie bóstwa rolnicze, z sierpem, oddzielającym niebo od ziemi ${ }^{36}$.

Zaprezentowane powyżej interpretacje, szczególnie te dotyczące paleolitycznych przedstawień kobiecych są różnorodne, często sprzeczne, ale odkrywają możliwe sposoby postrzegania. Oczywiste jest, że nigdy nie będziemy ich pewni, stawiamy tylko hipotezy, co zresztą czyni sztu-

33 E. Bullanda, Kult Bogini-matki w kulturach prehistorii $i$ etnologii, „Światowid”, t. 18, 1939/1945, s. 7-8.

34 W. Antoniewicz, Historia sztuki najdawniejszych społeczeństw pierwotnych, t. 1, Warszawa 1959.

35 B. Wyszomirska, Figure sculpture and buriel customs of north and north-east Europa's neolithic hunter-gatherer cultures, Lund 1984.

36 N. Kalicz, Clay Gods. The Neolithic Period and the Copper Age in Hungary, Budapest 1980 . 
kę pradziejową i tego, kto się za nią kryje, tak ciekawym, bo tajemniczym.

Przy uwzględnieniu kontekstu kultury magicznej, związanej z synkretycznym, opartym na animistycznej wizji świata paradygmatem, konieczne jest "całościowe", interdyscyplinarne podejście do badanych przedstawień. Kryterium estetyczne nie jest w tym wypadku jednym charakteryzującym dzieło sztuki. Należy uwzględnić wszelkie dostępne nam aspekty funkcjonowania danych społeczności, powiązać sferę życia dawnych społeczeństw z wydzielaną przez nas sferą sztuki. I traktować ją jako przejaw ludzkiej działalności symbolicznej, przybliżający nas do rozumienia sposobu działania, myślenia i postrzegania pradziejowych społeczeństw ${ }^{37}$. Próbę takiego ujęcia sztuki pradziejowej możemy odnaleźć w przedstawionym przez Wernera Herzoga filmie dokumentalnym Jaskinia zapomnianych snów, podejmującym próbę odczytania świata paleolitycznego zbieraczo-łowcy uchwyconego $\mathrm{w}$ odkrytej przypadkowo jaskini Chauveta. Jak czytamy w jednej z recenzji, Herzog w charakterystyczny dla siebie poetycko-filozoficzny sposób uzmysławia nam ogrom jej ukrytych znaczeńn ${ }^{38}$.

\section{Bibliografia}

Abramowa Z. A., Изображения человека в палеолитическом искустве Евразии, Moskwa - Leningrad 1966.

Antoniewicz W., Historia sztuki najdawniejszych społeczeństw pierwotnych, t. 1, Warszawa 1959.

Blocker H. G., The Aesthetics of Primitive Art, University Press of America, Lanham, MD 1994.

Buchowski M., Burszta W., O założeniach interpretacji antropologicznej, Warszawa 1992.

Bugaj E., Problemy interpretacji zjawisk sztuki w archeologii w kontekście nieoczywistości sztuki, w: Estetyka w archeologii, Gdańsk 2003, s. 11-20.

Bullanda E., Kult Bogini-matki w kulturach prehistorii i etnologii, „Światowid”, t. $18,1939 / 1945$.

Conrad J., Przedmowa, w: idem, Murzyn z załogi "Narcyza", Warszawa 1961.

Drössler R., Wenus epoki lodowcowej, Warszawa 1983.

37 E. Bugaj, op. cit., s. 7; Estetyka w archeologii. Antropomorfizacje w pradziejach i starożytności, red. E. Bugaj, A. P. Kowalski, Poznań 2010; A. P. Kowalski, Mit a piękno. Z badań nad pochodzeniem sztuki, Bydgoszcz 2013; A. Kuczyńska, op. cit.

38 J. Wróblewski, Okiem krokodyla. Recenzja filmu: "Jaskinia zapomnianych snów 3D", reż. Werner Herzog, „Polityka”, 6 maja 2011. 
Eliade M., Historia wierzeń i idei religijnych, t. 1: Od epoki kamiennej do misteriów eleuzyńskich, Warszawa 1988.

Estetyka w archeologii. Antropomorfizacje w pradziejach $i$ starożytności, red. E. Bugaj, A. P. Kowalski, Poznań 2010.

Florczak Z., Sztuka łamie milczenie. Z prahistorii plastyki, Kraków 1974.

Gralewski J., Sztuka prymitywna i jej pozycja w rozwoju sztuki, „Przegląd Filozoficzny" 1949.

Heidegger M., Budować, mieszkać, myśleć. Eseje wybrane, Warszawa 1977.

Janson H. W., Historia sztuki. Od czasów najdawniejszych po dzień dzisiejszy, Warszawa 1993.

Kalicz N., Clay Gods. The Neolithic Period and the Copper Age in Hungary, Budapest 1980.

Kobylińska E., Narodziny sztuki jako efekt „odczarowania” świata, „Studia Metodologiczne", t. 26, 1991, s. 25-45.

Kowalski A. P., Mit a piękno. Z badań nad pochodzeniem sztuki, Bydgoszcz 2013.

Kuczyńska A., Analiza górnopaleolitycznych przedstawień antropomorficznych z obszaru Europy i Syberii w kontekście kultury typu magicznego, "Zeszyty Naukowe Towarzystwa Doktorantów UJ - Nauki Społeczne", t. 1, 2011, nr 2, s. 50-59.

Kuczyńska-Zonik A., Paleolityczna Wenus. Górnopaleolityczne przedstawienia antropomorficzne z Europy Środkowo-Wschodniej, Wyd. Uniwersytetu Rzeszowskiego, Rzeszów 2014.

Lévi-Strauss C., Antropologia strukturalna, Warszawa 1970.

Lévi-Strauss C., Myśl nieoswojona, PWN, Warszawa 1969.

McCoid C. N., McDermott L., Toward Decolonizing Gender: Female Vision in the Upper Paleolithic, "American Anthropologist, New Series”, vol. 98, 1996, no. 2.

McDermott L., Self - representation in upper paleolithic female figurines, "Current Anthropology", vol. 37, 1996.

Meringer R., Einige primäre Gefühle des Menschen, ihr mimischer und sprachlicher Ausdruck, „Wörter und Sachen“ 1913, z. 5, s. 129-171.

Nougier L. R., Sztuka pradziejowa, w: Sztuka świata, red. I. Kumińska, Warszawa 1989.

Ossowski S., U podstaw estetyki, Warszawa 1958.

Śliwa M., Perspektywa wielokulturowości w estetyce, w: Granice dyscyplinarne w humanistyce, red. J. Kowalewski, W. Piasek, M. Śliwa, Olsztyn 2006, s. 203-211.

Tokariew S. A., Pierwotne formy religii i ich rozwój, Warszawa 1969.

Wendt H., Szukatem Adama, Warszawa 1960.

Wróblewski J., Okiem krokodyla. Recenzja filmu: "Jaskinia zapomnianych snów 3D“, reż. Werner Herzog, „Polityka”, 6 maja 2011.

Wyszomirska B., Figure sculpture and buriel customs of north and north-east Europa's neolithichunter-gatherer cultures, Lund 1984. 


\section{Streszczenie}

Tematem niniejszego artykułu jest próba spojrzenia na estetykę pradziejową z uwzględnieniem perspektywy synkretyzmu kulturowego. W pierwszej części artykułu przedstawiono krótką charakterystykę kultury typu magicznego, $\mathrm{w}$ kolejnej zaś poddano analizie kobiece przedstawienia figuralne z epoki paleolitu i neolitu. Ukazano zależność w sposobie zdobywania pożywienia i tworzenia się kanonu przedstawiania postaci ludzkiej u paleolitycznych zbieraczo-łowców i neolitycznych społeczności wczesnorolnych. W artykule zostały również zaprezentowane wybrane koncepcje interpretujące występowanie figuralnych przedstawień kobiecych, wskazujące jednoznacznie na głębię ich ukrytych znaczeń.

Słowa kluczowe: estetyka pradziejowa, sztuka pradziejowa, kultura typu magicznego, synkretyzm kulturowy, przedstawienia antropomorficzne, kobiece przedstawienia figuralne

\section{Summary}

\section{Aesthetics of Primitive Art. Figurative Female Presentations in the European Art of the Stone Age}

The article attempts to view primitive aesthetics from the perspective of cultural syncretism. In the first part of the article, a brief characteristics of the culture of magic is presented, and further, figurative female representations of the Palaeolithic and Neolithic Eras are analysed. A dependency has been shown between the ways in which food was gathered and forming the canon of the human figure representation in Palaeolithic collectors-hunters and Neolithic early-agricultural societies. The article also presents selected interpretation concepts for the occurrences of figurative female representations that unequivocally indicate their deep hidden meanings.

Keywords: primitive aesthetics, primitive art, culture of magic, cultural syncretism, anthropomorphic presentation, figurative female presentation 